\title{
Effect of Dietary Probiotics (Lactobacillus acidophilus) on the Growth Performance of Labeo Rohita
}

\section{Amit Sharma, S Kumar and S.K. Raghuvanshi*}

P.G. Department of Zoology, Bareilly College, MJP Rohilkhand University, Bareilly, UP, India

*Corresponding Author: S.K. Raghuvanshi, Department of Zoology, Bareilly College, Bareilly, Utter Pradesh, India.
Received: January 25, 2022

Published: January 31, 2022

(C) All rights are reserved by $\mathbf{S . K}$.

Raghuvanshi., et al.

\begin{abstract}
The present study was carried out to evaluate the influence of dietary supplementation of probiotic bacteria (Lactobacillus acidophilus), on growth performance of Labeo rohita. The probiotic L. acidophilus was procured from the market and the feed was prepared by crushing the basal food with probiotic bacteria in different combinations. The feeding trials were conducted in triplicate for 60 days, to determine the effect of dietary probiotics on growth status of fish. For this, the live fishes $(L$. rohita) were captured from Sagar Taal, Budaun, U.P. After acclimatization for 10 days, the fishes with similar body weight were distributed randomly into five treatment groups at Department of Zoology, Bareilly College, Bareilly, U.P. These fishes were given basal feed containing L. acidophilus in five concentrations viz., $0.5\left(\mathrm{~T}_{1}\right), 1.0\left(\mathrm{~T}_{2}\right), 1.5\left(\mathrm{~T}_{3}\right), 2.0\left(\mathrm{~T}_{4}\right)$ and $2.5\left(\mathrm{~T}_{5}\right)$. The control group $\left(\mathrm{T}_{0}\right)$ was fed basal food only, without $L$. acidophilus for the same period. Growth was analysed by measuring body length and weight, after the interval of every 15 days (at $15,30,45$ and 60 days). Two treatment groups $\left(\mathrm{T}_{4}\right.$ and $\mathrm{T}_{5}$ ) showed better growth of fishes, than any other treatment group. Group $\mathrm{T}_{4}$ showed a weight gain of $20.51 \pm 0.64 \%$, while the percentage length gain was $16.40 \pm 0.43 \%$. Similarly, the performance of group $\mathrm{T}_{5}$ was also found good (weight gain $20.22 \pm 0.61 \%$, length gain $17.05 \pm 0.08 \%$ ). On the other hand, the results of control treatment were comparatively poor (weight gain $19.50 \pm 0.49 \%$, length gain $15.37 \pm 0.08 \%$ ). These results suggest that L. acidophilus can be used as an effective probiotic @ 2\% or more in the form of dietary supplement, for L. rohita in aquaculture practices.
\end{abstract}

Keywords: Feed, Probiotic; Lactobacillus; Growth Performance; Labeo rohita

\section{Introduction}

Aquaculture possesses great potential to meet the increasing demands of the world in terms of high biological-value protein. Now a days, advanced rearing techniques and practices of nutritional improvement have promoted the aquaculture at large scale [1-4]. Aquaculture production in India has shown remarkable growth during the past six decades from a very small amount of 0.75 million tons in 1950-51 to 9.38 million tons in 2012-13 [5]. In India, freshwater fin fish production is dominated by three Cyprinid species, namely, rohu (Labeo rohita), catla (Catla catla) and mrigal (Cirrhinus mrigala), which contribute about $87 \%$ of the total freshwater fish production [6]. Labeo rohita (rohu) is an impor- tant freshwater fish and most preferred species usually cultured in Asia, specifically in the Indian subcontinent, because of the rapid growth and higher adequacy to consumers $[7,8]$. India is by far the largest producer of rohu followed by Bangladesh and Myanmar [9].

The appearance of diseases is a major obstacle in sustainable aquaculture production [10]. The conventional technique for disease control, such as antibiotics and antimicrobial drugs, are being used since last few years, but they have limited success in preventing fish diseases. Probiotics, therefore, are a good strategy for controlling the microbial infections with a great potential to replace antibiotics $[11,12]$. 
Probiotics are considered as microbes that have been employed as dietary supplement to enhance fish growth factors as length, weight gain, better survival rate, stress tolerance, improved gut flora, health of host, immunity enhancement and also to improve water quality parameters [13-26]. The widely used microbial strains as probiotics in aquaculture are Lactobacillus, Bacillus, Saccharomyces, Pseudomonas, Bifidobacteria and Vibrio [27]. Regular application of probiotics is done to maintain the desired population of good bacteria in human and animal nutrition is well documented [28], and they began to be applied in aquaculture sector recently $[3,29-31]$.

Lactobacillus, as a main group of probiotics, is employed by several workers in terms of animal nutrition, to enhance the growth performance, survival success, feeding efficacy, and to prevent the intestinal ailments and anti-nutritional factors present in the feedstuffs $[13,21]$. Lactobacillus has also been applied to increase the equilibrium of good microbes in gastrointestinal tract, resulting in overall good health of animals [21,23].

Keeping this view in mind, the present study was conducted to examine the influence of Lactobacillus acidophilus as probiotics, and its dietary supplement for growth promotion in Labeo rohita. The results of this study will be very helpful in understanding the growth responses of L. rohita towards probiotics, and thereby will enhance our knowledge for the healthy use of probiotics to flourish the aquaculture industry.

\section{Materials and Methods}

\section{Experimental design}

The live samples of L. rohita were collected from a pond Sagar Tal (2803'01.8'N 7907'55.5'E) located near Nawada in Budaun and were utilized as experimental animals in the present study. The collected fishes were stocked in properly washed glass aquaria at Department of Zoology, Bareilly College, Bareilly, U.P. ( $28^{\circ} 21^{\prime} 21.7^{\prime \prime} \mathrm{N} 79^{\circ} 25^{\prime} 35.6^{\prime \prime} \mathrm{E}$ ), where they were acclimatized for 10 days only. Aerators were kept connected to fish aquaria to maintain an optimum dissolved oxygen level. During the acclimatization period, fishes were provided with powdered basal feed (soya bean meal 25\%, mustard/groundnut oil cake 25\%, rice bran 38\%, wheat flour $10 \%$, vitamins and mineral mixture $2 \%$ ), crushed in mortar and pestle, twice daily.
After acclimatization period, length-weight measurement was done for all experimental fishes and recorded. In the control $\left(\mathrm{T}_{0}\right)$ group, the fishes were fed with normal basal feed for next 60 days. While in second group, the fishes were fed with basal food $+L$. acidophilus, in the concentrations of $0.5 \%\left(\mathrm{~T}_{1}\right), 1.0 \%\left(\mathrm{~T}_{2}\right), 1.5 \%$ $\left(\mathrm{T}_{3}\right), 2.0 \%\left(\mathrm{~T}_{4}\right)$ and $2.5 \%\left(\mathrm{~T}_{5}\right)$, respectively, for 60 days. Thus, for L. acidophilus probiotics treatment, five aquaria were used, while single aquarium was employed as control. Thus, the fishes with similar weights were collected to stock in 6 different aquaria $(\mathrm{n}=$ 10 fishes/aquarium containing 70 liters water). The water quality parameters of each experimental container were analyzed for temperature, $\mathrm{pH}$, and dissolved oxygen at fortnight intervals [29]. Temperature was measured by digital thermometer, $\mathrm{pH}$ was measured by using universal pH papers, while dissolved oxygen was determined by Winkler method [32,33].

\begin{tabular}{|l|c|c|c|c|c|c|}
\hline \multirow{2}{*}{ Ingredients } & \multicolumn{7}{|c|}{ Percentage composition of Experimental } \\
\cline { 2 - 7 } & $\mathbf{T}_{\mathbf{0}}$ & $\mathbf{T}_{\mathbf{1}}$ & $\mathbf{T}_{\mathbf{2}}$ & $\mathbf{T}_{\mathbf{3}}$ & $\mathbf{T}_{\mathbf{4}}$ & $\mathbf{T}_{\mathbf{5}}$ \\
\hline Rice Bran & 38.0 & 37.5 & 37.0 & 37.0 & 37.0 & 37.0 \\
\hline Soya bean meal & 25.0 & 25.0 & 25.0 & 24.5 & 24.5 & 24.5 \\
\hline Mustard oil cake & 25.0 & 25.0 & 25.0 & 25.0 & 24.5 & 24.5 \\
\hline Wheat flour & 10.0 & 10.0 & 10.0 & 10.0 & 10.0 & 9.5 \\
\hline $\begin{array}{l}\text { Vitamins and } \\
\text { minerals }\end{array}$ & 2.0 & 2.0 & 2.0 & 2.0 & 2.0 & 2.0 \\
\hline L. acidophilus & - & 0.5 & 1.0 & 1.5 & 2.0 & 2.5 \\
\hline
\end{tabular}

Table 1: Percentage composition of different ingredients in the experimental diet.

\section{Growth measurements}

For the determination of growth, weight and length of each fish in all three groups were recorded at the start of experiment, by using electronic balance and standard scale. After a regular interval of every 15 days, individual fishes were picked separately from each treatment group, and they were subjected to length-weight measurement, up to 60 days. Sampling was done at 15 days interval till 60 days to evaluate the length gain and weight gain by experimental organisms. The initial as well as final length and weight were used to calculate other growth parameters, such as net length gain, net weight gain, percentage length gain and percentage weight gain. The parameters used for the calculation of growth performance, were determined by using the standard formulae [30], as underNet Length gain $=$ Final length - Initial length 
Percentage Length Gain = $100 \times$ (Final Length-Initial length) $/$ Initial length

Net Weight gain $=$ Final weight - Initial weight

Percentage Weight Gain = $100 \times$ (Final weight - Initial weight $)$ / Initial weight

\section{Statistical analysis}

The mean values of multiple observations were calculated along with their standard deviations. Descriptive statistics and One-way analysis of variance (ANOVA) were employed to reach on meaningful conclusions, with the help of Data analysis pack of MS-EXCEL in Windows 10.

\section{Results}

\section{Water quality}

Water quality parameter such as temperature, dissolved oxygen and $\mathrm{pH}$ were monitored with their minimum and maximum range for the normal growth and survival of Labeo rohita (Table 2). All the excretory solid wastes were removed after every $24 \mathrm{hrs}$. by siphoning method.

\begin{tabular}{|l|c|c|c|}
\hline Range & Temperature $\left({ }^{\circ} \mathbf{C}\right)$ & $\begin{array}{c}\text { Dissolved Oxygen } \\
(\mathbf{p p m})\end{array}$ & $\mathbf{p H}$ \\
\hline Minimum & 19.5 & 5.5 & 7.20 \\
\hline Maximum & 28.5 & 6.5 & 8.10 \\
\hline
\end{tabular}

Table 2: Range of selected water quality parameters.

\section{Growth performance}

The present study was carried out for a period of 60 days on L. rohita, where they were fed with five different experimental diets, viz. $\mathrm{T}_{1}$ (basal diet $+0.5 \%$ probiotic), $\mathrm{T}_{2}$ (basal diet $+1.0 \%$ probiotic), $\mathrm{T}_{3}$ (basal diet $+1.5 \%$ probiotic), $\mathrm{T} 4$ (basal diet $+2.0 \%$ probiotic) and $\mathrm{T}_{5}$ (basal diet $+2.5 \%$ probiotic). The diet without probiotic serves as the control diet $\left(\mathrm{T}_{0}\right)$. The percentage composition of different ingredients in the basal diet and the concentration of probiotic (L. acidophilus) are given in table 1. The formulation of feed was in accordance with the nutrient requirement of Indian major carps (L. rohita, C. catla and C. mrigala) for better growth as reported by many authors [34,35].

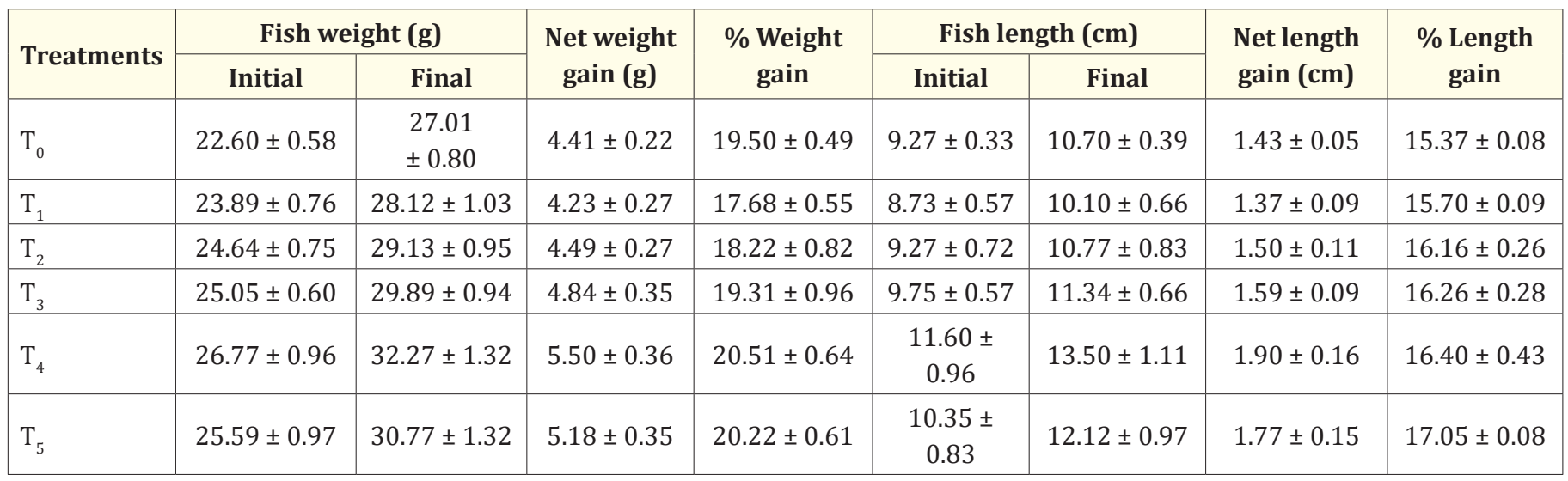

Table 3: Growth parameters of rohu (L. rohita), fed with different experimental diets (mean \pm SD).

The average increment in length $(\mathrm{cm})$ and weight $(\mathrm{g})$, percentage weight gain as well as percentage length gain in L rohita, fed with different experimental diets, are summarized in table 3 , which shows that the incorporation of probiotic L. acidophilus enhanced the growth performance of L. rohita in the present study. The growth of L. rohita was found increased in all the treatments, except treatment $\mathrm{T}_{1}$, as compared to control. Highest average net weight gain was found in $\mathrm{T}_{4}$ group $(5.50 \pm 0.36 \mathrm{~g})$ and lowest was found in $\mathrm{T}_{1}$ group $(4.23 \pm 0.27 \mathrm{~g})$.

The percentage gain in length and weight after 60 days in the experimental treatments was $17.05 \pm 0.08 \%$ in $\mathrm{T}_{5}$ and $20.51 \pm$ 
$0.64 \%$ in $\mathrm{T}_{4}$, respectively, which were higher than any other treatments (Table 3). When the data was subjected to single factor ANOVA analysis, no treatment was found significantly superior $(\mathrm{P}$ $n s, \mathrm{n}=60)$. But based on performance, treatment $\mathrm{T}_{4}(2.0 \%$ concen- tration of L. acidophilus) was found superior to others, in terms of growth promotion. Other statistical parameters were worked out in the form of descriptive statistics and are summarized in table 4.

\begin{tabular}{|l|c|c|c|c|c|c|}
\hline \multirow{2}{*}{ Parameters } & \multicolumn{7}{|c|}{ Treatments } \\
\cline { 2 - 7 } & $\mathbf{T}_{\mathbf{0}}$ & $\mathbf{T}_{\mathbf{1}}$ & $\mathbf{T}_{\mathbf{2}}$ & $\mathbf{T}_{\mathbf{3}}$ & $\mathbf{T}_{\mathbf{4}}$ & $\mathbf{T}_{\mathbf{5}}$ \\
\hline Mean & 17.26 & 17.62 & 18.36 & 18.92 & 20.96 & 19.66 \\
\hline Standard Error & 2.47 & 2.78 & 2.83 & 2.84 & 2.86 & 2.85 \\
\hline Median & 16.65 & 17.00 & 17.70 & 18.19 & 20.14 & 18.85 \\
\hline Standard Deviation & 7.82 & 8.78 & 8.96 & 8.99 & 9.03 & 9.00 \\
\hline Sample Variance & 61.22 & 77.12 & 80.29 & 80.73 & 81.55 & 80.98 \\
\hline Range & 17.74 & 19.39 & 19.86 & 20.14 & 20.67 & 20.42 \\
\hline Minimum & 9.27 & 8.73 & 9.27 & 9.75 & 11.60 & 10.35 \\
\hline Maximum & 27.01 & 28.12 & 29.13 & 29.89 & 32.27 & 30.77 \\
\hline Sum & 172.58 & 176.17 & 183.58 & 189.21 & 209.63 & 196.62 \\
\hline Count & 10.00 & 10.00 & 10.00 & 10.00 & 10.00 & 10.00 \\
\hline Confidence Level (95.0\%) & 5.60 & 6.28 & 6.41 & 6.43 & 6.46 & 6.44 \\
\hline
\end{tabular}

Table 4: Descriptive Statistics for various Experimental Treatments.

The percentage length gain and percentage weight gain in all treatments were plotted in the form of graph (Figure1), and it is clear from the graph that percentage length gain was progressively increasing from treatment $\mathrm{T}_{1}$ to $\mathrm{T}_{5}$. On the other hand, percentage weight gain was increased from $\mathrm{T}_{1}$ to $\mathrm{T}_{4}$, and then again decreased $\mathrm{a}$ little bid in $\mathrm{T}_{5}$, which suggests the maximum assimilation of food by fish at this concentration. Beyond the maximum limit, no more probiotic food could be helpful in weight gain. Therefore, the optimum concentration of L. acidophilus in growth promotion of L. rohita is found to be $2.0-2.5 \%$, during the present study.

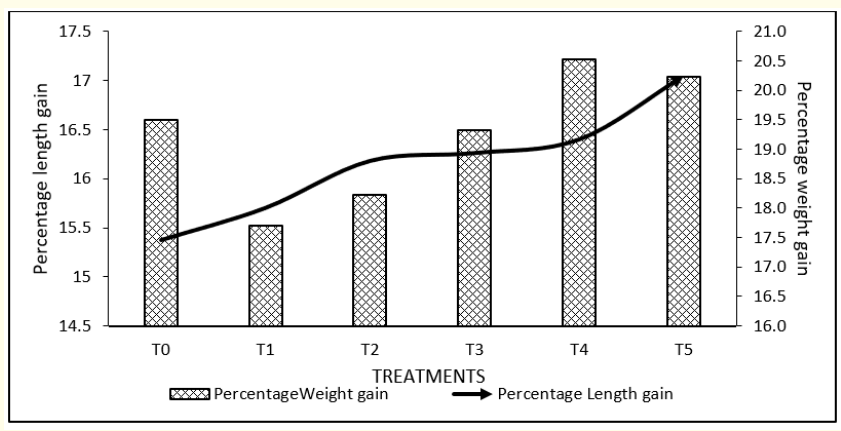

Figure 1: Percentage length gain and percentage weight gain among different experimental treatments.

\section{Discussion}

There has been a good number of research concerning the impacts of probiotics on farmed fish species suggesting improvement gained in adherence and formation of colonies within guts [36] and better growth function and nutritional efficiency [37]. The increased growth rate among L. rohita using Bacillus circulans extracted from the gut of the fingerlings may again prove the facilitative effects of probiotics on fish growth rates [38].

The positive impacts of probiotics can also be traced to their role in boosting appetite which is achieved through production of vitamins and detoxification of feeds or because of decomposition of undigested compounds [3]. This might be attributed to the generation of certain enzymes such as peptide by probiotic bacteria that hydrolyze micro molecular compounds converting them to peptides and amino acids $[29,39,40]$. In this study, the use of probiotics caused an increase in body weight, to the extent that treatments $\mathrm{T}_{4}$ and $\mathrm{T}_{5}$ with 2.0 and $2.5 \%$ concentrations of L. acidophilus, respectively, resulted in the highest body weight and growth rate compared to the control group $\left(\mathrm{T}_{0}\right)$. The improved body weight and length gain observed in this study might be attributed to factors mentioned above. The increased growth rate among farm-raised fish consuming probiotic added feeds may be accounted for by the 
increased reactions of digestive enzymes, morphological transformation of the fish guts or the probiotic fermentation within the guts [38].

In the present study, dietary administration of Lactobacillus acidophilus improved growth parameters (net length gain, net weight gain, percentage length gain and percentage weight gain) in the fish fed a supplemented diet. Growth factors were more favourable in the fish fed diets $\mathrm{T}_{4}$ and $\mathrm{T}_{5}$ than the fish fed diet $\mathrm{T}_{0}$ (control). A similar effect has been reported using "kelp" which includes brown algae Ascophyllum nodosum, Sargasumm spp and Laminaria digitata, as dietary supplements [41]. Further research is needed to determine the effects on growth status of Lactobacillus in other major cultured species.

The beneficial influence of probiotic treatment on growth was possibly attributed due to the alteration of the intestinal microflora [42]. The probiotic consists of L. acidophilus in different concentrations (Table 1). The lactic acid bacteria are considered as beneficial residents of the fish's intestinal ecosystem by producing bacteriocins, which inhibit growth of certain fish pathogens, thus, positively affect the hosts' micro-flora [43]. Furthermore, probiotic incorporated feed had a definite role in enhancing the growth of channel catfish, turbot, and carp larvae [44]. The beneficial effects of probiotics in larval rearing have also been demonstrated [45]. Incorporation of probiotic in the basal diet enhances growth and nutrient utilization in mrigal fry [46]. The study conducted on mode of action of probiotic reveals that the probiotics suppresses the harmful bacteria and thus the nutrients can be spared for use by the host animal. Probiotics also improve the enzyme activity in the gut by producing several enzymes not produced by the host [37].

Water temperature influences several living and non-living components of aquatic ecosystem, directly as well as indirectly. It also resembles the dynamics of the living organisms such as Biochemical and physiological behaviour of aquatic ecosystem [47]. Water temperature was found minimum during winter months and showed a rising trend towards the summer months. The dissolved oxygen showed an indirect relationship with water temperature and was minimum during the peak summers. Winter increase in dissolved oxygen has also been reported by many workers [48-50]. Increased levels of dissolved oxygen during winter months may be due to the increased solubility of oxygen at lower temperature. Too high or too low dissolved oxygen concentration can affect aquatic life and eventually influence water quality [51]. $\mathrm{pH}$ of water is also one of the most important chemical parameters since aquatic organisms are well adapted to specific $\mathrm{pH}$ range and do not withstand abrupt changes in it [52].

There was no disease observed during the experimental period. This may be due to the supplementation of beneficial bacteria, which was very well justified, when the turbot (Scophthalmus maximus) larvae fed rotifer with probiotics (lactic acid bacteria and spores of Bacillus toyoi) not only improved the growth rate of fish, but also probably released antibiotics, there by not being affected by certain opportunistic vibrios [53].

In the present study, the incorporation of probiotic above 2.0\% level increases growth but further inclusion of Probiotic, the growth shows a decreasing trend. This may be due to the overdose of probiotic which suppress growth. As probiotic supplementation appears to be an important consideration in enhancing survival and growth at different stages of carp larvae, various useful strains of bacteria, exogenous enzymes and essential nutrients must be judiciously incorporated in fish feeds to achieve better fish production. As this is a preliminary study on the use of probiotic in Labeo rohita of Tarai region of U.P., the dose standardization and duration of application needs further research.

\section{Conclusion}

It can be concluded that the prepared experimental feed with probiotic Lactobacillus acidophilus enhance the various growth parameters of rohu (Labeo rohita). The prepared experimental diet used in the present study, incorporated with 2.0-2.5\% Lactobacillus acidophilus is found useful to optimize the growth of Labeo rohita.

\section{Bibliography}

1. Javaid MY. "Aquaculture Development in Pakistan". Aquaculture in Asia, Asian Fish Society, India (1990): 291-301.

2. Mishra S. "Probiotics: Possible application in aquaculture". Fish Chimes 21.1 (2001): 31-37.

3. Irianto A and Austin B. "Use of probiotics to control furunculosis in Rainbow trout, Oncorhynchus mykiss (Walbaum)". Journal of Fish Disease 25 (2002a): 333-342. 
4. Sahu MK. "Probiotics in aquaculture: importance and future perspectives". Indian Journal of Microbiology 48.3 (2008): 299308.

5. Department of Fisheries. "Handbook of Fisheries Statistics". Ministry of Fisheries, animal husbandry and Dairying, Govt. of India (2015).

6. “ICLARM. The World Fish Center annual report” (2001).

7. Khan MA., et al. "Growth and body composition of rohu, Labeo rohita (Hamilton), fed compound diet: Winter feeding and rearing to marketable size". Journal of Applied Ichthyology 20 (2004): 265-270.

8. Giri SS. "Effects of dietary supplementation of potential probiotic Bacillus subtilis VSG1 singularly or in combination with Lactobacillus plantarum VSG 3 or/and Pseudomonas aeruginosa VSG 2 on the growth, immunity, and disease resistance of Labeo rohita". Aquaculture Nutrition 20.2 (2014): 163-171.

9. FAO. Fisheries and Aquaculture Information and Statistics Branch (2017).

10. Verschuere L. "Probiotic bacteria as biological control agents in aquaculture". Microbiology and Molecular Biology Reviews 64.4 (2000): 655-671.

11. Taoka Y. "Growth, stress tolerance and non-specific immune response of Japanese flounder Paralichthys olivaceus to probiotics in a closed recirculating system". Fisheries Science 72.2 (2006): 310-321.

12. Panigrahi A and Azad IS. "Microbial intervention for better fish health in aquaculture: the Indian scenario". Fish Physiology and Biochemistry 33.4 (2007): 429-440.

13. Ring $\varnothing \mathrm{E}$ and Gatesoupe FJ. "Lactic acid bacteria in fish: A review”. Aquaculture 160.3-4 (1998): 177-203.

14. Nikoskelainen S.. et al. "Characterization of the properties of human- and dairy-derived probiotics for prevention of infectious diseases in fish". Applied and Environmental Microbiology 67.6 (2001): 2430-2435.

15. Cruce S and Goulet J. "Improving probiotic survival rates". Food Technology 55.10 (2001): 36-42.

16. Ibrahim F., et al. "Effect of temperature on in vitro adhesion of potential fish probiotics". Microbial Ecology in Health and Disease 16.4 (2004): 222-227.
17. Yanbo W. and Zirong X. "Effect of probiotics for common carp (Cyprinus carpio) based on growth performance and digestive enzyme activities". Animal Feed Science and Technology 127.34 (2006): 283-292.

18. Chaudhary A and Qazi JI. "Influence of a probiotic Pseudomonas pseudoalcaligenes fermented feed on growth performance of rohu (Labeo rohita) fingerlings". Punjab University Journal of Zoology 22.1-2 (2007): 41-56.

19. Bagheri T., et al. "Growth, Survival and Gut Microbial Load of Rainbow Trout (Onchorhynchus mykiss) Fry given Diet Supplemented with Probiotic during the Two Months of First Feeding". Turkish Journal of Fisheries and Aquatic Sciences 8 (2008): 43-48.

20. Gatesoupe FJ. "Updating the Importance of Lactic Acid Bacteria in Fish Farming: Natural Occurrence and Probiotic Treatments". JMMB 14.1-3 (2008): 107-114.

21. Suzer C., et al. "Lactobacillus sp. bacteria as probiotics in Gilthead Sea Bream (Sparus aurata, L.) Larvae: Effects on growth performance and digestive enzyme activities". Aquaculture 280.1-4 (2008): 140-145.

22. Essa MA., et al. "Effect of different dietary probiotics on growth, feed utilization and digestive enzymes activities of Nile Tilapia, Oreochromis niloticus". Journal - The Arab Aquaculture Society 5.2 (2010): 143-162.

23. Faramarzi M., et al. "The Investigation of Lactobacillus acidophilus as Probiotic on Growth Performance and Disease Resistance of Rainbow Trout (Oncorhynchus mykiss)". AmericanEurasian Journal of Scientific Research 6.1 (2011): 32-38.

24. Allameh SK., et al. "Effects of Probiotic Bacteria on Fish Performance". Advanced Technology in Clinical Microbiology 1 (2017): 2.

25. Das N., et al. "Effect of feed probiotic on the growth and their colonization performance on the intestine of rohu (Labeo rohita)". International Journal of Current Microbiology and Applied Sciences 9.3 (2020): 806-823.

26. Chaudhary A., et al. "Impact of Bacillus subtilis supplemented feed on growth and biochemical constituents in Labeo rohita fingerlings". Journal of King Saud University - Science 33 (2021).

27. Kolndadacha OD., et al. "The role of probiotics in aquaculture in Nigeria- a review". Canadian Journal of Fisheries and Aquatic Sciences 5.1 (2011): 8-15. 
28. Fuller R. "History and development of probiotics". The Scientific Basis. Chapman and Hall, London (1992): 1-8.

29. Gatesoupe FJ. "The use of probiotics in aquaculture”. Aquaculture 180.1-2 (1999): 147- 165.

30. Irianto A and Austin B. "Probiotics in aquaculture". Journal of Fish Diseases 25.11 (2002b): 633-642.

31. Balcazar JL., et al. "Probiotics: a tool for the future of fish and shellfish health management". Journal of Aquaculture 19 (2004): 239-242.

32. Trivedi RK and Goel PK. "Chemical and Biological Methods for Water Pollution Studies". Environmental Publication, Karad, India Environmental publications (1986).

33. APHA AWWA WEF. "Standard methods for the examination of water and wastewater (21 $1^{\text {st }}$ Ed.)", American Public Health Association, American Water Works Association and Water Environment Federation, Washington, D.C., U.S.A. (2005).

34. Samantaray K and Mohanty SS. "Interactions of dietary levels of protein and energy on fingerling snakehead, Channa striata". Aquaculture 156 (1997): 241- 249.

35. Venugopal MN and Keshavanath P. "Formulation, stability and keeping quality of three pelleted feeds used in carp culture". Fishery Technology 2.1 (1984): 18-23.

36. Renuakradhya KM and Varghese TJ. "Protein requirement of the carps, Catla catla (Hamiltom) and Labeo rohita (Hamilton)". Proceedings of the Indian Academy of Sciences 95.1 (1986): 103-107.

37. Nayak SK. "Probiotics and immunity: A fish perspective". Fish and Shellfish Immunology 29.1 (2010): 2-14.

38. Ringo E., et al. "Lactic acid bacteria versus pathogens in the gastrointestinal tract of fish". Aquaculture Research 41 (2010): 451-467.

39. Ghosh K., et al. "Characterization of bacilli isolated from gut of rohu, Labeo rohita, fingerlings and its significance in digestion". The Journal of Applied Aquaculture 12.3 (2002): 33-42.

40. Fuller AR. "Probiotics in man and animals". The Journal of Applied Bacteriology 66.5 (1989): 365-378.

41. Kennedy SB., et al. "Bacterial management strategies for stock enhancement of warm water marine fish: a case study with common snook (Centropomus undecimalis)". Bulletin of Marine Science 62 (1998): 573- 588.
42. Rengpipat S., et al. "Effects of a probiotic bacterium on black tiger shrimp Penaeus monodon survival and growth". Aquaculture 167.3-4 (1998): 301-313.

43. "Uso de harina de kelp (Macrocystispyrifera) en alimentos para camaron". Avances en Nutricio'nAcuı'cola V-Memorias del Quinto Simposium Internacional deNutricio'n Acuícola, Mérida, México 5 (1998): 227-266.

44. Singh LA., et al. "Effect of dietary probiotic supplement on growth and survival of Indian major carp seeds". Asian Journal of Animal Sciences 9.2 (2014): 174-177.

45. Peng L., et al. "Dietary brewer's yeast and the prebiotic Grobiotic $^{\mathrm{TM}} \mathrm{AE}$ influence growth performance, immune responses and resistance of hybrid striped bass (Morone chrysops $\times M$. saxatilis) to Streptococcus iniae infection". Aquaculture 231 (2004): 445-456.

46. Swain SK., et al. "Effect of a probiotics supplements on growth Nutrient utilization and carcass composition in mrigal fry". Journal of Aquaculture 4 (1996): 29-35.

47. Shyamala R., et al. "Physicochemical Analysis of Borewell Water Samples of Telungupalayam Area in Coimbatore District, Tamilnadu, India”. E-Journal of Chemistry 5.4 (2008): 924-929.

48. Pennak RW. "Field and experimental limnology of three Colorado mountain lakes”. Ecology 19.3 (1968): 505-520.

49. Das SM and Pathani SS. "Some physicochemical and biological indicators of pollution in lake Nainital, Kumaun (U.P.)". Indian Journal of Ecology 5.1 (1978): 7-16.

50. Thirupathaiah M., et al. "Analysis of water quality using physico-chemical parameters in lower manair reservoir of Karimnagar district, Andhra Pradesh". International Journal of Environmental Sciences 3.1 (2012): 172-180.

51. Kemker C. "Dissolved oxygen" Fundamentals of Environmental Measurements Fondriest Environmental, Inc (2013).

52. George JP. "Aquatic Ecosystem: Structure, Degradation, Strategies for Management". Recent Advances in Ecobiological Research, M. P (Ed). A. P. H. Publ. House, New Delhi (1997): 603.

53. Gatesoupe, F.J. "The effect of three strains of lactic bacteria on the production rate of rotifers, Brachionus plicatilis, and their dietary value for larval turbot, Scophthalmus maximum". Aquaculture 96 (1991): 335-342. 


\section{Assets from publication with us}

- Prompt Acknowledgement after receiving the article

- Thorough Double blinded peer review

- Rapid Publication

- Issue of Publication Certificate

- High visibility of your Published work

Website: www.actascientific.com/

Submit Article: www.actascientific.com/submission.php

Email us: editor@actascientific.com

Contact us: +919182824667 